\title{
Spots of bother
}

\author{
Samantha Mary-Anne Morgan, ${ }^{1}$ Barnaby Flower, ${ }^{2}$ Mark A Samaan ${ }^{3}$
}

${ }^{1}$ Barnet General Hospital, London, UK

${ }^{2}$ Newham University Hospital, London, UK

${ }^{3}$ Department of Gastroenterology, University College London Hospital, London, UK

\section{Correspondence to}

Dr Mark A Samaan, markasamaan@gmail.com

Accepted 28 November 2015

\section{DESCRIPTION}

A 24-year-old man presented with a 2-day history of a purpuric rash affecting his lower limbs, associated with fever, malaise and anorexia. He had fistulising, stricturing Crohn's disease with an end ileostomy and two enterocutaneous fistulae requiring long-term parenteral nutrition $(\mathrm{PN})$ via a singlelumen Hickman line. His only medication was analgaesia and vitamin $\mathrm{B}_{12}$. He had not received regular steroids or immunosuppressive therapy for over 2 years.

On examination, he was febrile and tachycardic but not hypotensive. There were no cardiac murmurs and chest auscultation was unremarkable. His abdomen was soft and stoma output unchanged. A purpuric rash was visible on his lower limbs (figure 1). There was no meningism and examination of eyes, ears and throat was unremarkable.

Blood tests revealed haemoglobin $15.2 \mathrm{~g} / \mathrm{dL}$, white cell count 11.5 (neutrophils 9.5, eosinophils $0.8) \times 10^{6} / \mathrm{mL}$, platelet count $247 \times 10^{9} / \mathrm{L}$, erythrocyte sedimentation rate $14 \mathrm{~mm} / \mathrm{h}, \mathrm{C}$ reactive protein $82.1 \mathrm{mg} / \mathrm{L}$, sodium $122 \mathrm{mmol} / \mathrm{L}$, potassium $4.6 \mathrm{mmol} / \mathrm{L}$, urea $13.8 \mathrm{mmol} / \mathrm{L}$, creatinine $89 \mu \mathrm{mol} / \mathrm{L}$, bilirubin $21 \mu \mathrm{mol} / \mathrm{L}$, albumin $28 \mathrm{~g} / \mathrm{L}$, alanine transaminase $133 \mathrm{U} / \mathrm{L}$, alkaline phosphatase $673 \mathrm{U} / \mathrm{L}$, international normalised ratio 1.4 and activated partial thromboplastin time $42 \mathrm{~s}$. Chest X-ray and urinalysis were normal. An ultrasound and CT scan of the abdomen showed a fatty liver consistent with $\mathrm{PN}$-associated liver disease but no other abnormalities.

Candida glabrata was isolated from Hickman line blood cultures after $24 \mathrm{~h}$ incubation. The line was removed and 2 weeks of intravenous caspofungin started. The rash resolved within $48 \mathrm{~h}$ of treatment and inflammatory markers normalised. A transthoracic echocardiogram, vasculitis screen and complement levels were normal.

\section{Learning points}

Parenteral nutrition is an important risk factor for invasive candidiasis; Candida glabrata accounts for approximately $17 \%$ of positive cultures. Clinicians should remain alert to the possibility of disseminated candidiasis in susceptible patients.

- The appearance of skin lesions can be the first clinical manifestation of acute disseminated candidiasis and this diagnosis should be considered in susceptible patients presenting in this manner.

\section{Competing interests None declared.}

Patient consent Obtained.

Provenance and peer review Not commissioned; externally peer reviewed.
To cite: Morgan SM-A, Flower B, Samaan MA. BMJ Case Rep Published online: [please include Day Month Year] doi:10.1136/bcr-2015212721

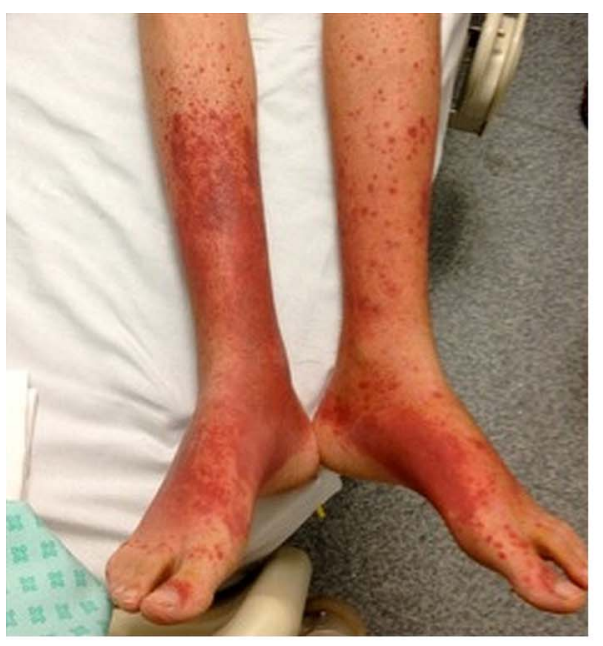

Purpuric rash

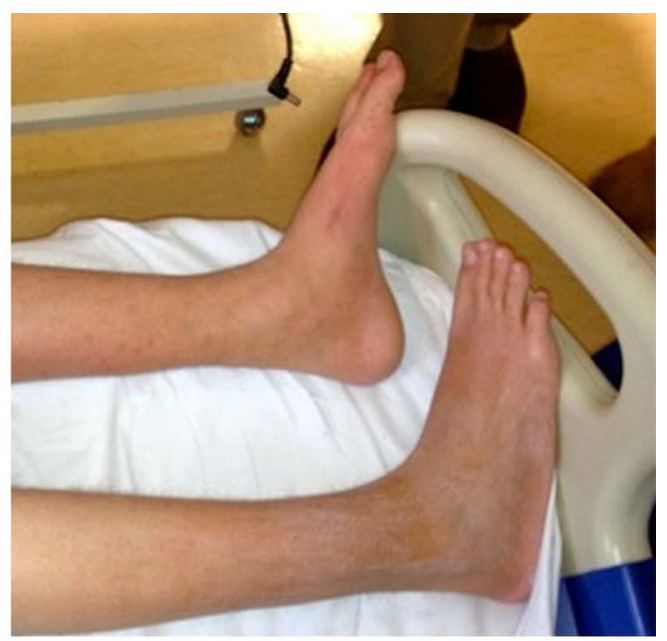

48hours after treatment with Caspofungin
Figure 1 Purpuric rash pretreatment and post-treatment. 
Copyright 2015 BMJ Publishing Group. All rights reserved. For permission to reuse any of this content visit http://group.bmj.com/group/rights-licensing/permissions.

BMJ Case Report Fellows may re-use this article for personal use and teaching without any further permission.

Become a Fellow of BMJ Case Reports today and you can:

- Submit as many cases as you like

- Enjoy fast sympathetic peer review and rapid publication of accepted articles

- Access all the published articles

- Re-use any of the published material for personal use and teaching without further permission

For information on Institutional Fellowships contact consortiasales@bmjgroup.com

Visit casereports.bmj.com for more articles like this and to become a Fellow 